Nuclear test

Japan's response to an earthquake highlights both the promise and the pitfalls of nuclear power at a critical time for its future.

( $\mathrm{n}$ the face of it, the Japanese government and the Tokyo Electric Power Company seem to have reacted competently when an earthquake occurred some 20 kilometres from a huge nuclear facility on 16 July (see page 392 ).

The incident, at the Kashiwazaki-Kariwa plant in Niigata prefecture on Japan's western coast, could have been serious. Seven reactors on the largest single-site nuclear-power facility in the world were hit by a quake of magnitude 6.8, exceeding their design capacity of 6.5 .

Prime Minister Shinzo Abe responded swiftly to the event, directly instructing the operator to come clean about the full facts of the case. The operator duly grovelled about some incomplete information that was released in the hours after the earthquake.

The nuclear fall-out from the incident was, thankfully, minimal. Despite a few minute leaks into cooling water and the atmosphere, and the upending of some wheelie bins containing low-level nuclear waste, the reactors and their materials seem to have been reassuringly well contained. That's a substantial engineering achievement.

At the same time, questions are being asked about why this facility was built on a seismically active fault line. Japan manages to combine an intense hunger for nuclear-generating capacity with a dearth of seismically inactive sites. But last week's event was the third time in as many years that a nuclear power station in Japan has been subjected to an earthquake more powerful than it was designed to withstand. It would seem that the nuclear regulator, the Nuclear Safety Commission, needs to involve seismologists more fully in its site approval process - and to raise its standards. This need not preclude the construction of new facilities: nuclear power stations in Japan have already been designed and built to deal with earthquakes of magnitude 8 .

The power company's response also seemed a little shaky in the immediate aftermath of the quake - saying that emergency-response teams were difficult to assemble because it was the Marine Day holiday, for example, was unlikely to inspire public confidence. But the subsequent flow of information on the situation inside the plant seemed reassuringly complete. Regular updates for the local population and a comprehensive release of data on the nature of the faults caused by the earthquake combined to suggest that both the operator and the government have learned a lot - including the sublime benefits of transparency - from their shaky track record in this realm in past decades.

A larger pall is cast by the commercial consequences of the inevitable decision to close the seven reactors on the site until there has been a full assessment of the damage done. The loss of eight gigawatts of electricalgenerating capacity (enough to power half of Tokyo) is a major blow despite the wellplanned nature of Japan's generating system.

"The Japanese government has learned about the sublime benefits of transparency regarding nuclear power." In a precautionary move, major industrial corporations have been asked to plan reductions in their peak power consumption to help see the grid through the summer peak in electricity demand.

Global warming and high energy prices have put nuclear power firmly back in the picture around the world. Plans are afoot to build new plants in Britain and the United States, and China and India look set to press ahead with nuclear power on a significant scale.

Investors in planned nuclear plants continue to worry about waste disposal and liability issues, and look to sympathetic governments to provide assurance regarding these. Lurking in the back of their minds, however, is the ever-present risk of accidents of the sort that played havoc with the global industry at Three Mile Island, Pennsylvania, in 1979 and at Chernobyl in 1986. Another such event could undermine political support for nuclear power and so up-end their planned investments altogether, possibly before a single megawatt of power is generated and sold.

On balance, last week's events go some way towards bearing out the industry line that such unfortunate incidents can be averted. For that to remain the case will demand not revolutionary, next-generation technology, but rather a combination of diligent engineering, careful regulation and public transparency.

\title{
Storm brewing
}

\section{It's the season of discord at US National Oceanic and Atmospheric Administration.}

$\mathrm{T}$ his year's hurricane season in the Atlantic Ocean has so far seen just two named storms: Andrea and Barry. But a much bigger tempest has been brewing in Miami, Florida, for several months - let's call it Hurricane Bill.

In January, Bill Proenza took over as director of the US National Hurricane Center, the forecast facility in Miami, Florida, that aims to keep the US public safe from storms. At best it was a lateral career move from his previous post at the National Weather Service into a position that Proenza had not applied to fill.

Within weeks of assuming the centre's directorship, Proenza landed himself in hot water (see Nature 447, 514-515; 2007). Among other things, he criticized how much money the centre's parent agency, the National Oceanic and Atmospheric Administration (NOAA), was spending on anniversary celebrations. More pointedly, he publicly bemoaned the lack of a detailed plan to replace the QuikSCAT satellite, which among its many jobs provides data on ocean winds to the team that forecasts hurricanes in the Atlantic.

This criticism did not sit well with his bosses or his employees, many 